\title{
Short-Term Changes in Fertility Attributes and Soil Organic Matter Caused by the Addition of EM Bokashis in Two Tropical Soils
}

\author{
Carlos Eduardo Pacheco Lima, ${ }^{1}$ Mariana Rodrigues Fontenelle, ${ }^{1}$ \\ Luciana Rodrigues Borba Silva, ${ }^{2}$ Daiane Costa Soares, ${ }^{2}$ \\ Antônio Williams Moita, ${ }^{1}$ Daniel Basílio Zandonadi, ${ }^{1}$ \\ Ronessa Bartolomeu Souza, ${ }^{3}$ and Carlos Alberto Lopes ${ }^{1}$ \\ ${ }^{1}$ Embrapa Vegetables, Rodovia BR-060 Km 09, Caixa Postal 218, 70351-970 Brasília, DF, Brazil \\ ${ }^{2}$ Faculdades ICESP/Promove de Brasília, QE 11, Área Especial C/D, Guará I, 71020-631 Brasília, DF, Brazil \\ ${ }^{3}$ Embrapa, Parque Estação Biológica, s/n, 70770-902 Brasília, DF, Brazil
}

Correspondence should be addressed to Carlos Eduardo Pacheco Lima; carlos.pacheco-lima@embrapa.br

Received 21 September 2015; Revised 19 November 2015; Accepted 23 November 2015

Academic Editor: Manuel Tejada

\begin{abstract}
Copyright (C) 2015 Carlos Eduardo Pacheco Lima et al. This is an open access article distributed under the Creative Commons Attribution License, which permits unrestricted use, distribution, and reproduction in any medium, provided the original work is properly cited.
\end{abstract}

\begin{abstract}
The present work aimed to evaluate the behavior of ten fertility attributes of soil organic matter physical fractions and total organic carbon upon addition of three EM Bokashis to a Rhodic Ferralsol (FRr) and a Dystric Cambisol (CMd). An experiment was carried out in greenhouse in which the soils were placed into plastic trays and cultivated with tomato. A completely randomized design was used with four repetitions and factorial scheme of $2 \times 3+2$, consisting of two soils (FRr and CMd), three EM Bokashis (Poultry Manure Bokashi (BPM); CNPH Bokashi (BC); and Cattle Manure Bokashi (BCM)), and two controls (both soils without addition of Bokashi). The following fertility attributes were evaluated: $\mathrm{pH}, \mathrm{Ca}^{2+}, \mathrm{Mg}^{2+}, \mathrm{K}^{+}, \mathrm{Na}^{+}, \mathrm{P}, \mathrm{SB}, \mathrm{H}+\mathrm{Al}, \mathrm{CEC}$, and $V$. Particulate organic carbon (POC) and mineral-associated organic carbon (MOC) and total organic carbon (TOC) were also investigated. Finally, the Principal Component Analysis was conducted in order to identify possible patterns related to soils when fertilized with EM Bokashi. The addition of EM Bokashi increased the soil fertility and contents of POC. Different EM Bokashi presents distinguished effects on each soil. The PCA suggests that BPM presents higher capacity to modify the analyzed chemical attributes.
\end{abstract}

\section{Introduction}

Several papers have been focused on the need of reaching more sustainable production systems [1-3]. In addition, the need for a global increase of agricultural production to feed a growing population is still a key question that has not been solved, as demonstrated by Ray et al. [4]. This way, the more efficient management of natural resources in agriculture, so as to ally the conservation of natural resources, the social development, and the economic viability, constitutes a current challenge. Therefore, the adoption of organic fertilization is an alternative. Nevertheless, many challenges still exist in order to achieve a wider reach of organic agriculture around the world. For instance, Seufert et al. [5], by meta-analysis, compared the productivity of organic and conventional production systems in various agricultural crops and established that the first system presents numbers $25 \%$ smaller than the latter. Among the possible causes for this smaller productivity can be cited aspects related to an inefficient nutrients supply. In this sense, it becomes necessary to fill eventual blanks in the knowledge about the effects of adopting organic production inputs in the soils, an area of extreme importance for the development of organic agriculture.

The use of organic residues such as fertilizers, apart from stimulating the recycling of various materials and diminishing the use of nonrenewable minerals, also makes available, at 
different proportions, the nutrients necessary for plant development. Moreover, it may also contribute with increments in the soil quality, with emphasis on the improvement in the contents of soil organic matter (SOM) and all benefits associated therewith, with positive effects on agricultural crops $[6,7]$. Among the organic fertilizers commonly used, the EM Bokashi plays a special role, generally constituted by agroindustrial residues, such as flours or brans and manure, which are inoculated with a solution of effective microorganisms (EM) containing anaerobic and aerobic organisms, favoring the oxidative decomposition and enzymatic fermentation.

In order to understand the behavior of soil organic matter and its effect on soil quality it is important that labile and recalcitrant soil organic matters are quantified. In this sense, granulometric fractionation of organic matter allows quantifying two distinct organic fractions, the particulate organic carbon (POC) and the mineral-associated organic carbon (MOC), which may be used to verify such balance. The POC fraction consists of materials promptly available for decomposition, such as leaves, roots, and animal remains. These components are associated with the sand fraction of soil, which presents particles with diameter larger than or equal to $53 \mu \mathrm{m}$, constituting an estimate of SOM's labile fraction. As for the MOC fraction, it can be understood as an estimate of SOM's recalcitrant fraction and is composed of organic matter in advanced stage of decomposition, being strongly linked to the minerals of soil, and with diameter smaller than $53 \mu \mathrm{m}[8]$.

Although there are several published papers about the effects of organic residues on soil quality, just some of them aim to be related to the use of EM Bokashi. There are differences in the effects observed for the simple organic fertilizers input on soil chemical attributes and those proportioned to them enriched with EM [6]. This lack of information, especially important for tropical soils, hampers the comparison of results and their discussion. It is possible that the effects of different EM Bokashi on soil chemical attributes should be dependent on different organic inputs and soil types and this is an important theme to actual and future scientific research and to improve organic fertilization. Considering all these aspects, the present work had the objective of evaluating the effects of adding different EM Bokashi on fertility and soil organic matter attributes, in two different soils commonly found in Brazil (a Rhodic Ferralsol (FRr) and a Dystric Cambisol (CMd)).

\section{Material and Methods}

The experiment was implemented in a greenhouse at the Sector of Experimental Fields of Embrapa Vegetables, located at the rural area of Brasília, Distrito Federal, Brazil (geographic coordinates $15^{\circ} 56^{\prime} \mathrm{S}$ and $48^{\circ} 08^{\prime} \mathrm{W}$, altitude of $997.6 \mathrm{~m}$ ). The experiment was conducted in the autumn of 2013. According to the Köppen classification, the region has Aw-type climate (tropical savanna with concentration of rain in the summer). For execution of experiment, tomato crop (Solanum lycopersicum) cultivar San Vito was employed, in two cycles, until beginning of fructification. Both cycles had duration of 30
TABLE 1: Contents of nitrogen (N), carbon (C), sulfur (S), and moisture of the three EM Bokashis used in the experiment.

\begin{tabular}{lcccc}
\hline Bokashi & $\mathrm{N}$ & $\begin{array}{c}\mathrm{C} \\
\mathrm{g} \mathrm{kg}^{-1} \text { of dry matter }\end{array}$ & $\begin{array}{c}\text { S } \\
\text { Moisture } \\
\mathrm{g} \mathrm{kg}^{-1}\end{array}$ \\
\hline BCM & 19.8 & 197.1 & 13.0 & 23.5 \\
BC & 31.0 & 262.0 & 6.4 & 94.7 \\
BPM & 28.6 & 223.0 & 8.7 & 44.8 \\
\hline
\end{tabular}

days, with an interval of 30 days between them. Throughout this whole period irrigation was performed in the experimental allotments.

The experiment was carried out in plastic trays of $40 \times$ $20 \times 10 \mathrm{~cm}$, with capacity of approximately $10 \mathrm{~kg}$ of soil. The design was completely randomized comprising four repetitions in factorial scheme $2 \times 3+2$, with two soils (Rhodic Ferralsol (FRr) and Dystric Cambisol (CMd)), three EM Bokashi types (Cattle Manure Bokashi (BCM), Poultry Manure Bokashi (BPM), and CNPH Bokashi (BC)), and two controls (the same two soils, nonfertilized).

The BCM and BPM can be differentiated as to the origin of manure, bovine or poultry, respectively. In turn, the $\mathrm{CNPH}$ Bokashi (BC), produced in Embrapa Vegetables, is composed of plant residues and poultry litter, besides other organic compounds, such as bone meal and castor cake. All EM Bokashis were produced anaerobically in the presence of EM and BPM and BCM are acquired commercially.

The amount of EM Bokashi added was determined based on the total nitrogen $(\mathrm{N})$ contents of Bokashi types, as well as on the requirements of tomato crop used in the experiment. To each soil type were added, respectively, $650 \mathrm{~g} / \mathrm{box}$ of BCM, $460 \mathrm{~g} / \mathrm{box}$ of BPM, and $450 \mathrm{~g} / \mathrm{box}$ of BC. The mass of each EM Bokashi was added so as to reach a $\mathrm{N}$ content of $2,500 \mathrm{~kg} \mathrm{ha}^{-1}$. Thus, it is emphasized that the same amount of this production input was added to all experimental allotments. Soil sampling was performed after two cycles of tomato cultivation. The basic chemical composition, as well as the moisture level of used EM Bokashi, can be found in Table 1.

The fertility analyses of the soils were carried out according to protocols available in EMBRAPA $[9,10]$. The contents of $\mathrm{Ca}^{2+}, \mathrm{Mg}^{2+}, \mathrm{Na}^{+}, \mathrm{K}^{+}$, potential acidity $(\mathrm{H}+\mathrm{Al})$, and available $\mathrm{P}$ (Mehlich-1) were determined. In addition, the $\mathrm{pH}$ values, exchangeable bases (SB), cation exchange capacity (CEC), and base saturation $(V)$ were quantified.

The determination of TOC contents and physical fractions was accomplished by the Walkley-Black method. The physical fractionation of soil organic matter was performed by the method proposed by Cambardella and Elliot [8]. For this, $20 \mathrm{~g}$ of dried soil air samples was weighed and placed into centrifuge flasks with screw caps. To these was added $60 \mathrm{~mL}$ of sodium hexametaphosphate, and the flasks were subjected to horizontal agitation for $15 \mathrm{~h}$. Next, the contents retained in sieve of $53 \mu \mathrm{m}$ were washed and dried in incubator at $40^{\circ} \mathrm{C}$. Subsequently, the contents were weighed and the POC contents were determined. Finally, the data obtained for POC were corrected according to the texture of soils. The MOC 
TABLE 2: $P$ values of the evaluated soil fertility attributes and of the physical fractions of the soil organic matter and for the contents of TOC data.

\begin{tabular}{|c|c|c|c|c|c|c|c|c|c|c|c|c|c|}
\hline \multirow{2}{*}{ Source of variation } & $\mathrm{pH}$ & $\mathrm{Ca}^{2+}$ & $\mathrm{Mg}^{2+}$ & $\mathrm{K}^{+}$ & $\mathrm{Na}^{+}$ & $\mathrm{P}$ & SB & $\mathrm{H}+\mathrm{Al}$ & $T$ & V & POC $^{*}$ & MOC & TOC \\
\hline & \multicolumn{13}{|c|}{$\operatorname{Pr}>\mathrm{FC}$} \\
\hline Controls $*$ factorial & 0.00 & 0.15 & 0.00 & 0.00 & 0.00 & 0.00 & 0.86 & 0.00 & 0.00 & 0.00 & 0.00 & 0.36 & 0.38 \\
\hline Soils & 0.00 & 0.00 & 0.04 & 0.00 & 0.37 & 0.00 & 0.00 & 0.00 & 0.00 & 0.00 & 0.00 & 0.00 & 0.00 \\
\hline EM Bokashi & 0.00 & 0.66 & 0.01 & 0.00 & 0.00 & 0.00 & 0.87 & 0.00 & 0.41 & 0.00 & 0.53 & 0.01 & 0.02 \\
\hline Soils $*$ EM Bokashi & 0.00 & 0.37 & 0.46 & 0.02 & 0.00 & 0.00 & 0.28 & 0.00 & 0.03 & 0.00 & 0.01 & 0.01 & 0.23 \\
\hline
\end{tabular}

${ }^{*}$ Results referring to the ANOVA performed for the data transformed by the Box-Cox method.

contents were quantified through the difference between the contents of TOC and POC.

The data were then verified as to their normal distribution. Once this was confirmed, they were subjected to the analysis of variance by $F$ test at $5 \%$. When this test turned out significant, the differences between the averages were attested by the Scott-Knott test at the same significance level. Further, the relationships between the variables were determined by Pearson correlations and the Principal Component Analysis (PCA) was conducted to group similar treatments.

\section{Results and Discussion}

Normal distribution was verified for the data regarding all analyzed variables, except for that corresponding to the POC fraction. For this variable, transformation of data was then performed using the Box-Cox method.

Table 2 offers the $P$ values of ANOVA. Significant differences were found between the means of EM Bokashi treatments and the controls for the variables $\mathrm{pH}, \mathrm{Mg}^{2+}, \mathrm{K}^{+}$, $\mathrm{Na}^{+}, \mathrm{P}, \mathrm{H}+\mathrm{Al}, T, V$, and POC. However, no effects of EM Bokashi were verified for $\mathrm{Ca}^{2+}, \mathrm{SB}, \mathrm{MOC}$, and TOC compared to the controls. Differently, the interaction between the two evaluated factors was significant for $\mathrm{pH}, \mathrm{K}^{+}, \mathrm{Na}^{+}, \mathrm{P}$, $\mathrm{H}+\mathrm{Al}, T, V, \mathrm{MOC}$, and POC.

The action of EM Bokashi as soil conditioners became evident by the higher $\mathrm{pH}$ values found for the treatments that received this input, independently of soil used (Table 3). Similar results were found by Boechat et al. [6] that evaluated the effects of application of five organic residues in Ferralsol chemical attributes. Probably, the increase of soil $\mathrm{pH}$ is linked with the use of limestone or lime in the EM Bokashi formulation, with the objective of eliminating parasites and pathogens microorganisms possibly present in the organic residues. The unfolding of factor soil inside each level of factor EM Bokashi further showed that the highest values of $\mathrm{pH}$ were found for CMd when compared to FRr. This fact must be related to the higher base saturation in the CMd, which makes evident a more basic reaction in comparison to $\mathrm{FRr}$; further, it suggests lower occupation by cations of acid hydrolysis, such as aluminum $\left(\mathrm{Al}^{3+}\right)$. Moreover, the addition of different EM Bokashi shows distinct results in the $\mathrm{pH}$ according to the used soil. In this sense, it was observed that, for $\mathrm{CMd}$, the highest $\mathrm{pH}$ values were found upon application of BPM, whereas the addition of BC or BCM increased the $\mathrm{pH}$ to similar levels, which were lower than that for BPM.
As for $\mathrm{FRr}$, the highest $\mathrm{pH}$ values were registered upon addition of $\mathrm{BC}$ and BCM. These results suggest complex relationships between the EM Bokashi and soils. Then, it is possible that the complexity of these relationships has been normally disregarded when recommendations have been made for fertilization with these organic production inputs, which may lead to suboptimal utilization of their potential. These complex relationships must be dependent on mineralsoil organic matter interactions and further studies will be necessary to provide a better understanding of them.

Behavior similar to the $\mathrm{pH}$ was demonstrated for the base saturation. The relationship between these two variables in tropical soils has been known for a long time, as can be seen by the work of van Raij et al. [11]. This way, here was observed a higher base saturation for the group of soils that received addition of EM Bokashi. Moreover, the unfolding of interaction of factors showed that the highest values of $V$ were found for CMd, independently of applied EM Bokashi. Brazilian Cambisols normally present lower influence of weathering processes than Ferralsols [12] and, therefore, commonly suffered lesser loss of basic cations, which may explain the higher values of $V$. For CMd, it was found that the higher $V$ was observed in samples treated with BPM compared with the other two evaluated EM Bokashis. In turn, in FRr it can be observed that $V$ maintained by BC was higher than those by the BPM and BCM. The contents of $\mathrm{Mg}^{2+}, \mathrm{Na}^{+}, \mathrm{K}^{+}$, and $\mathrm{P}$, besides the values of $V$ and $T$, were also superior for the treatments that received addition of EM Bokashi. The conjunct of these results made clear the fertility capacity of these inputs. Several papers had related the increased soil fertility due to the use of organic residues in Brazilian soils $[6,13,14]$. In this study, a very heterogeneous behavior was observed with respect to the potential fertility improvement provided by each EM Bokashi for each soil. In the FRr the different EM Bokashi maintained the following: $\mathrm{BC}$ and $\mathrm{BCM}$, higher $\mathrm{pH}$ values; $\mathrm{BPM}$ and $\mathrm{BC}$, higher $\mathrm{Mg}^{2+}$ and $\mathrm{P}$ contents; $\mathrm{BCM}$, higher $\mathrm{K}^{+}$contents and lower $\mathrm{Na}^{+}$ contents; $\mathrm{BC}$, lower $\mathrm{H}+\mathrm{Al}$ and higher $V$ values. In turn, for $\mathrm{CMd}$, it was observed that the EM Bokashi maintained the following: $\mathrm{BPM}$, higher $\mathrm{pH}$ and $V$, beyond lower $\mathrm{H}+\mathrm{Al} ; \mathrm{BC}$, higher $\mathrm{P}$ content; $\mathrm{BCM}$, higher $\mathrm{K}^{+}$content; $\mathrm{BC}$ and $\mathrm{BCM}$, higher CEC. The results of many other studies $[14,15]$ with organic fertilizers support this heterogeneity of effects in different soils and must be related with the various materials used in the composition and the production method of these inputs, the soil type, and the evaluation methods also. 
TABLE 3: Means of the fertility attributes evaluated in a FRr and a CMd fertilized with EM Bokashi and cultivated with tomato.

\begin{tabular}{|c|c|c|c|c|c|c|c|c|c|c|}
\hline \multirow{2}{*}{ Treatment } & \multirow{2}{*}{$\mathrm{pH}$} & $\mathrm{Ca}^{2+}$ & $\mathrm{Mg}^{2+}$ & \multirow[t]{2}{*}{$\mathrm{K}^{+}$} & $\mathrm{Na}^{+}$ & \multirow[t]{2}{*}{$\mathrm{P}$} & \multirow[t]{2}{*}{ SB } & $\mathrm{H}+\mathrm{Al}$ & \multirow[t]{2}{*}{ CEC } & \multirow{2}{*}{$\begin{array}{l}V \\
\%\end{array}$} \\
\hline & & \multicolumn{2}{|c|}{$\mathrm{cmol}_{\mathrm{c}} \mathrm{kg}^{-1}$} & & $\mathrm{mg} \mathrm{kg}^{-1}$ & & & $\mathrm{cmol}_{\mathrm{c}} \mathrm{kg}^{-1}$ & & \\
\hline \multicolumn{11}{|c|}{ Factorial $*$ controls } \\
\hline Factorial & $6.94 \mathrm{a}$ & $16.98^{\mathrm{ns}}$ & $4.94 \mathrm{a}$ & $420.83 \mathrm{a}$ & $22.00 \mathrm{a}$ & $481.46 \mathrm{a}$ & $23.10^{\mathrm{ns}}$ & $7.18 \mathrm{~b}$ & $30.28 \mathrm{a}$ & $77.24 \mathrm{a}$ \\
\hline Controls & $5.98 \mathrm{~b}$ & $15.05^{\mathrm{ns}}$ & $4.13 \mathrm{~b}$ & $189.50 \mathrm{~b}$ & $13.83 \mathrm{~b}$ & $228.04 \mathrm{~b}$ & $19.73^{\text {ns }}$ & $8.90 \mathrm{a}$ & $28.63 \mathrm{~b}$ & $69.62 \mathrm{~b}$ \\
\hline \multicolumn{11}{|c|}{ Soil } \\
\hline FRr & - & $18.41 \mathrm{a}$ & $5.07 \mathrm{a}$ & - & - & - & $24.86 \mathrm{a}$ & - & - & - \\
\hline CMd & - & $15.56 \mathrm{~b}$ & $4.82 \mathrm{a}$ & - & - & - & $21.33 \mathrm{~b}$ & - & - & - \\
\hline \multicolumn{11}{|c|}{ Bokashi } \\
\hline $\mathrm{BPM}$ & - & $16.67^{\mathrm{ns}}$ & $5.15 \mathrm{a}$ & - & - & - & $22.99^{\mathrm{ns}}$ & - & - & - \\
\hline $\mathrm{BC}$ & - & $17.36^{\mathrm{ns}}$ & $5.00 \mathrm{a}$ & - & - & - & $23.34^{\mathrm{ns}}$ & - & - & - \\
\hline $\mathrm{BCM}$ & - & $16.92^{\text {ns }}$ & $4.68 \mathrm{~b}$ & - & - & - & $22.96^{\mathrm{ns}}$ & - & - & - \\
\hline \multicolumn{11}{|c|}{ Unfolding of the soils inside each level of EM Bokashi } \\
\hline \multicolumn{11}{|c|}{ Soils $*$ BPM } \\
\hline $\mathrm{FRr} * \mathrm{BPM}$ & $6.02 \mathrm{~b}$ & - & - & $513.33 \mathrm{a}$ & $25.00 \mathrm{a}$ & $395.23 \mathrm{~b}$ & - & $10.23 \mathrm{a}$ & $35.69 \mathrm{a}$ & $71.40 \mathrm{~b}$ \\
\hline $\mathrm{CMd} * \mathrm{BPM}$ & $6.76 \mathrm{a}$ & - & - & $330.00 \mathrm{~b}$ & $21.67 \mathrm{~b}$ & $639.80 \mathrm{a}$ & - & $3.10 \mathrm{~b}$ & $23.64 \mathrm{~b}$ & $86.72 \mathrm{a}$ \\
\hline \multicolumn{11}{|c|}{ Soils $*$ BC } \\
\hline $\mathrm{FRr} * \mathrm{BC}$ & $6.13 \mathrm{~b}$ & - & - & $440.00 \mathrm{a}$ & $21.00 \mathrm{~b}$ & $361.27 \mathrm{~b}$ & - & $9.23 \mathrm{a}$ & $34.25 \mathrm{a}$ & $73.21 \mathrm{~b}$ \\
\hline $\mathrm{CMd} * \mathrm{BC}$ & $6.38 \mathrm{a}$ & - & - & $248.33 \mathrm{~b}$ & $23.67 \mathrm{a}$ & $794.27 \mathrm{a}$ & - & $4.70 \mathrm{~b}$ & $26.37 \mathrm{~b}$ & $82.31 \mathrm{a}$ \\
\hline \multicolumn{11}{|c|}{ Soils $*$ BCM } \\
\hline $\mathrm{FRr} * \mathrm{BCM}$ & $6.10 \mathrm{~b}$ & - & - & $560.00 \mathrm{a}$ & $20.67^{\mathrm{ns}}$ & $267.40 \mathrm{~b}$ & - & $10.43 \mathrm{a}$ & $34.56 \mathrm{a}$ & $69.81 \mathrm{~b}$ \\
\hline $\mathrm{CMd} * \mathrm{BCM}$ & $6.37 \mathrm{a}$ & - & - & $433.33 \mathrm{~b}$ & $20.00^{\mathrm{ns}}$ & $430.87 \mathrm{a}$ & - & $5.37 \mathrm{~b}$ & $27.16 \mathrm{~b}$ & $80.05 \mathrm{a}$ \\
\hline \multicolumn{11}{|c|}{ Unfolding of EM Bokashi inside each level of soil } \\
\hline \multicolumn{11}{|c|}{ LVd $*$ EM Bokashi } \\
\hline $\mathrm{FRr} * \mathrm{BPM}$ & $6.02 \mathrm{~b}$ & - & - & $523.33 \mathrm{~b}$ & $25.00 \mathrm{a}$ & $395.23 \mathrm{a}$ & - & $10.23 \mathrm{a}$ & $35.69^{\mathrm{ns}}$ & $71.40 \mathrm{~b}$ \\
\hline $\mathrm{FRr} * \mathrm{BC}$ & $6.13 \mathrm{a}$ & - & - & $440.00 \mathrm{c}$ & $21.00 \mathrm{~b}$ & $361.27 \mathrm{a}$ & - & $9.23 \mathrm{~b}$ & $34.25^{\mathrm{ns}}$ & $73.21 \mathrm{a}$ \\
\hline $\mathrm{FRr} * \mathrm{BCM}$ & $6.10 \mathrm{a}$ & - & - & $560.00 \mathrm{a}$ & $20.67 \mathrm{c}$ & $267.40 \mathrm{~b}$ & - & $10.43 \mathrm{a}$ & $34.55^{\mathrm{ns}}$ & $69.81 \mathrm{~b}$ \\
\hline \multicolumn{11}{|c|}{ CXbd $*$ EM Bokashi } \\
\hline $\mathrm{CMd} * \mathrm{BPM}$ & $6.76 \mathrm{a}$ & - & - & $330.00 \mathrm{~b}$ & $21.67 \mathrm{~b}$ & $639.80 \mathrm{~b}$ & - & $3.10 \mathrm{~b}$ & $23.64 \mathrm{~b}$ & $86.72 \mathrm{a}$ \\
\hline $\mathrm{CMd} * \mathrm{BC}$ & $6.38 \mathrm{~b}$ & - & - & $248.33 \mathrm{c}$ & $23.67 \mathrm{a}$ & 794.27 a & - & $4.70 \mathrm{a}$ & $26.37 \mathrm{a}$ & $82.31 \mathrm{~b}$ \\
\hline $\mathrm{CMd} * \mathrm{BCM}$ & $6.37 \mathrm{~b}$ & - & - & $433.33 \mathrm{a}$ & $20.00 \mathrm{~b}$ & $430.87 \mathrm{c}$ & - & $5.37 \mathrm{a}$ & 27.16 a & $80.05 \mathrm{~b}$ \\
\hline CV (\%) & 1.42 & 20.05 & 11.52 & 8.7 & 7.6 & 5.9 & 9.57 & 9.37 & 7.92 & 2.89 \\
\hline
\end{tabular}

Means followed by the same letter (column) do not differ among themselves by the Scott-Knott test at $5 \%$. ${ }^{\text {ns }}$ Nonsignificant at $5 \%$ by the $F$ test; $-=$ not evaluated; CMd = Dystric Cambisol; FRr = Rhodic Ferralsol; BPM = Poultry Manure Bokashi; BC = CNPH Bokashi; BCM = Cattle Manure Bokashi.

However, no effects were verified upon addition of EM Bokashi on the $\mathrm{Ca}^{2+}$ contents and SB values. Thus, the obtained results indicate an inefficiency of used organic fertilizers in supplying $\mathrm{Ca}^{2+}$ which when necessary must therefore be provided by some other source. Another possibility is that this result may be influenced by external sources of variation, as liming, that input high contents of this macronutrient and then mask the effects of EM Bokashi. Moreover, it is possible to infer about a strong relationship between the contents of $\mathrm{Ca}^{2+}$ and the values of SB in the studied soils. These relationships are according to the results of Abreu Jr. et al. [16] that analyzed the relationship between acidity and chemical properties of 26 Brazilian soils finding results that suggest that the mainly basic cations in those soils are $\mathrm{Ca}^{2+}$ and $\mathrm{Mg}^{2+}$. It is probably that the higher contents of $\mathrm{Ca}^{2+}$ and $\mathrm{Mg}^{2+}$ are linked with the use of limestone to correct the soil acidity and supply these cations. The interaction between the evaluated factors was not significant for $\mathrm{Ca}^{2+}, \mathrm{Mg}^{2+}$, and $\mathrm{SB}$. This way, it is possible to infer that these attributes suffered effect of individual factors. The analysis of results reveals that the content of $\mathrm{Ca}^{2+}$, as well as the values of $\mathrm{SB}$, was statistically different only for the soils, with higher contents being found in FRr. This fact must be related to the higher CEC of FRr, which increases its capacity of retaining cations. At this point it should also be emphasized that the employed soils were collected in area of agricultural production (CMd) or received addition of limestone for constitution of substrate (FRr); thus, absence of effect of treatments and differences between soils may also be related to the liming. In turn, the $F$ test for $\mathrm{Mg}^{2+}$ content was significant for the used soils and EM Bokashi. However, the Scott-Knott test at 5\% did not detect differences between the mean values of this macronutrient found for both soil types. As for the EM Bokashi, higher contents were observed in the samples fertilized with BPM and BC. 
TABLE 4: Means of MOC, POC, and TOC evaluated in FRr and CMd fertilized with Bokashi and cultivated with tomato.

\begin{tabular}{|c|c|c|c|}
\hline Treatment & \multicolumn{3}{|c|}{$\mathrm{g} \cdot \mathrm{kg}^{-1}$} \\
\hline \multicolumn{4}{|c|}{ Factorial $*$ additional } \\
\hline Factorial & $76.52^{\mathrm{ns}}$ & $24.35 \mathrm{a}$ & $100.87^{\text {ns }}$ \\
\hline Controls & $48.59^{\text {ns }}$ & $17.88 \mathrm{~b}$ & $66.47^{\text {ns }}$ \\
\hline \multicolumn{4}{|c|}{ Soil } \\
\hline $\mathrm{FRr}$ & - & - & $121.71 \mathrm{a}$ \\
\hline CMd & - & - & $80.03 \mathrm{~b}$ \\
\hline \multicolumn{4}{|c|}{ Bokashi } \\
\hline BPM & - & - & $100.04 \mathrm{~b}$ \\
\hline $\mathrm{BC}$ & - & - & $95.04 \mathrm{~b}$ \\
\hline $\mathrm{BCM}$ & - & - & $107.53 \mathrm{a}$ \\
\hline \multicolumn{4}{|c|}{ Unfolding of the soils inside each level of EM Bokashi } \\
\hline \multicolumn{4}{|c|}{ Soils $*$ BPM } \\
\hline $\mathrm{FRr} * \mathrm{BPM}$ & $84.25 \mathrm{a}$ & $35.80 \mathrm{a}$ & - \\
\hline $\mathrm{CMd} * \mathrm{BPM}$ & $69.91 \mathrm{~b}$ & $10.12 \mathrm{~b}$ & - \\
\hline \multicolumn{4}{|c|}{ Soils $*$ BC } \\
\hline $\mathrm{FRr} * \mathrm{BC}$ & $82.49 \mathrm{a}$ & $37.56 \mathrm{a}$ & - \\
\hline $\mathrm{CMd} * \mathrm{BC}$ & $58.64 \mathrm{~b}$ & $11.39 \mathrm{~b}$ & - \\
\hline \multicolumn{4}{|c|}{ Soils $*$ BCM } \\
\hline $\mathrm{FRr} * \mathrm{BCM}$ & $82.27^{\mathrm{ns}}$ & $42.76 \mathrm{a}$ & - \\
\hline $\mathrm{CMd} * \mathrm{BCM}$ & $81.56^{\mathrm{ns}}$ & $8.46 \mathrm{~b}$ & - \\
\hline \multicolumn{4}{|c|}{ Unfolding of EM Bokashi inside each level of soil } \\
\hline \multicolumn{4}{|c|}{$\mathrm{FRr} *$ EM Bokashi } \\
\hline $\mathrm{FRr} * \mathrm{BPM}$ & $84.25^{\mathrm{ns}}$ & $35.80^{\mathrm{ns}}$ & - \\
\hline $\mathrm{FRr} * \mathrm{BC}$ & $82.49^{\text {ns }}$ & $37.56^{\mathrm{ns}}$ & - \\
\hline $\mathrm{FRr} * \mathrm{BCM}$ & $82.27^{\mathrm{ns}}$ & $42.76^{\mathrm{ns}}$ & - \\
\hline \multicolumn{4}{|c|}{ CMd $*$ EM Bokashi } \\
\hline $\mathrm{CMd} * \mathrm{BPM}$ & $69.91 \mathrm{~b}$ & $10.12^{\mathrm{ns}}$ & - \\
\hline $\mathrm{CMd} * \mathrm{BC}$ & $58.64 \mathrm{c}$ & $11.39^{\mathrm{ns}}$ & - \\
\hline $\mathrm{CMd} * \mathrm{BCM}$ & $81.56 \mathrm{a}$ & $8.46^{\mathrm{ns}}$ & - \\
\hline CV (\%) & 14.24 & 8.79 & 12.57 \\
\hline
\end{tabular}

${ }^{*}$ Data transformed by Box-Cox method. Means followed by the same letter (column) do not differ among themselves by the Scott-Knott test at $5 \%$. ${ }^{n}$ Nonsignificant at $5 \%$ by the $F$ test; $-=$ not evaluated; CMd = Dystric Cambisol; FRr $=$ Rhodic Ferralsol; BPM = Poultry Manure Bokashi; BC $=$ CNPH Bokashi; BCM = Cattle Manure Bokashi.

Increases in the diversity of microorganisms and positive effects on the content of $\mathrm{P}, \mathrm{N}$, and $\mathrm{S}$ were attributed to the use of EM associated with organic residues by Namasivayam and Kirithiga [15]. Positive results of applying EM Bokashi and other organic residues of the fertility attributes of Brazilian soils have also been occasionally cited in the literature. For instance, Boechat et al. [6], evaluating the effects of organic residues mixed or not with EM Bokashi on a Xanthic Ferralsol, concluded that the last products may enhance and accelerate the degradation of organic residues, promoting positive effects on the liquid mineralization of $\mathrm{N}$ and on fertility attributes of soil. Further, Ourives et al. [17], evaluating the effect of an EM Bokashi applied so as to provide five different doses of $\mathrm{P}_{2} \mathrm{O}_{5}$ in a Rhodic Ferralsol, under pasture of Brachiaria brizantha, observed positive effects on the parameters related to the pasture quality and fertility attributes.
Generally there were observed high contents of nutrients in all treatments. In part, these high contents are due to an enrichment caused by the high capacity of EM Bokashi to supply these nutrients. When organic inputs with high fertility potential are added to the tropical soils the risk of lixiviation and its negative environmental impacts increases [18]. Additionally, use of high rates of poultry litter can increase the risk of $\mathrm{P}$ lixiviation in the form of organic $\mathrm{P}$. Successively fertilization with poultry litter or fertilization with this organic fertilizer after the mineral fertilization can increase the risk of $P$ lixiviation [19]. Then, rational uses of EM Bokashi are necessary.

The contents of TOC and its physical fractions, as well as their relationship with the evaluated factors, were also studied in the present work. The results available in Table 4 show that the addition of EM Bokashi only had effect in the POC 
fraction, when compared to the additional treatment. These results are probably related to the higher instability of this fraction and its greater response potential upon conduction of short-term experiments. Significant interaction between the evaluated factors was also found for POC. In this sense, $\mathrm{FRr}$ always presented higher contents than CMd, whereas no statistical differences were found between the contents maintained by the different EM Bokashi in both soils. These results probably demonstrate the higher potential for POC accumulation of FRr. Probably this result is linked to the strong granular structure in this soil that protected labile SOM against microbial attack and to the oxidic mineralogy forming strong intermolecular bonds with SOM [20].

No significant statistical differences were observed between the contents of MOC maintained by the factors compared to the control treatments. This fact may be related to the high stability of MOC fraction, which makes it little responsive to the soil management in short-term experiments. Similar behavior was found for TOC; this was an expected fact since in tropical soils the largest part of TOC is composed of material with high stability, quantified by the MOC fraction. In the present work, the mean of factorial treatments showed that the MOC fraction represented $75.9 \%$ of TOC. Differently, the means of control treatments demonstrated that this fraction corresponded to $73.1 \%$ of TOC. However, the lack of statistical difference between the mean contents of MOC and TOC between the factorial and controls treatments does not allow certainty that the addition of EM Bokashi promoted stabilization of SOM. The contents of MOC and TOC for the control and the factorial treatments showed relatively large numerical differences $\left(48.59 \mathrm{~g} \mathrm{~kg}^{-1}\right.$ and $76.52 \mathrm{~g} \mathrm{~kg}^{-1}$; $100.87 \mathrm{~g} \mathrm{~kg}^{-1}$ and $66.47 \mathrm{~g} \mathrm{~kg}^{-1}$, resp.), which may suggest that the lack of statistical significance is related to the high variation of obtained data. This is possibly a consequence of a supposed heterogeneity of EM Bokashi or, more probable, of high differences between the soils. Nevertheless, the lower sensitivity of MOC and TOC fractions to short-term alterations in superficial horizon in organic agriculture production systems has been related in works such as those of Loss et al. [21, 22].

For the MOC fraction significant effects of interaction between the factor soil and the factor EM Bokashi were observed. The unfolding of interaction shows that FRr maintained higher contents of this organic fraction for all EM Bokashis. EM Bokashi presented similar potential of MOC addition for the FRr, while maintaining different levels for the CMd. In this last soil BCM maintained higher contents of MOC, followed by BPM that maintained intermediated values and $\mathrm{BC}$ that added the lower ones. Moreover, it seems that FRr is less susceptible than CMd to changes in MOC contents caused by addition of these organic production inputs. This result again suggests complex relationships of cause and effect upon EM Bokashi addition to such distinct soils as those used in this work. To explain these results, it can be hypothesized that the natural presence of higher contents of stable organic matter in FRr, as well as the more effective mechanisms of stabilization of SOM in this soil, results in its smaller response to such additions. In the same way, it is also possible that CMd is more dependent on the addition of external

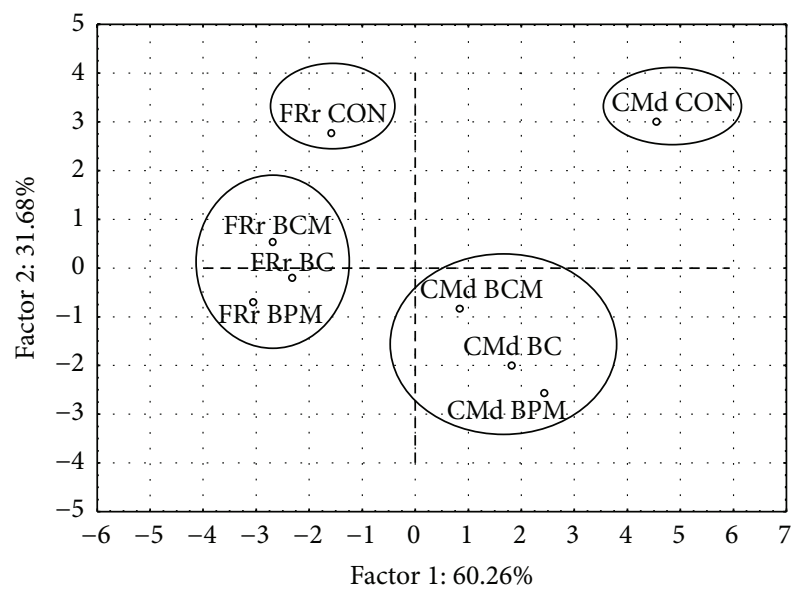

Figure 1: Principal Component Analysis of the evaluated cases (treatments).

sources of stabilized SOM than FRr, which is thus of extreme importance to improve the quality of CMd.

With regard to TOC, although no significant differences were found between the treatments that received EM Bokashi and those that did not, as well as for the interaction between the factors, individual effects were observed for the latter. This way, the highest TOC contents were found for FRr when compared to CMd. Further, the highest TOC contents were found in the soil samples that received BCM, followed by those that received $\mathrm{BPM}$ and $\mathrm{BC}$, which maintained similar contents.

The higher content of evaluated fractions and of TOC in FRr may be explained by various reasons. Six et al. [23] reported that stabilization of SOM is a consequence of a series of factors or processes, such as the recalcitrance of organic molecules, the link to the surface of clay minerals, or the inaccessibility of SOM to the microorganisms when protected in stable soil aggregates. In this sense, the content of recalcitrant fractions in the soils depends, among others, on the quality of provided organic compounds, the climatic conditions, and the soils properties [24, 25]. Brazilian Ferralsols have a strong granular structure as one of their main characteristics, the genesis of which may be strongly influenced by the elevated presence of iron and aluminum oxides in their mineralogical composition [26]. The physical protection of fresh SOM by occlusion in these stable aggregates is an important mechanism that restricts its decomposition in Ferralsols [27]. In addition, the organic molecules may be found stabilized by intermolecular bonds such as electrostatic attraction, hydrogen bonds, and exchange of ligands with the oxides and oxyhydroxides [28], constituents that are commonly found in higher amounts in Ferralsols. At last, the high degree of development promoted by weathering of Ferralsols may lead to a kind of "natural selection" of more stable organic molecules, this last process as suggested by Lorenz et al. [29].

The results of PCA are available in Figure 1. The PCA allows detecting the existence or not of anomalous samples, relationships between the measured variables, and relationships or groupings of samples [30]. The two first factors explained $91.94 \%$ of variance of the data, corresponding to an 
TABLE 5: Correlation between the first and the second factors and the variables adopted in the present work.

\begin{tabular}{lcc}
\hline Attributes & Factor 1 & Factor 2 \\
\hline $\mathrm{pH}$ & 0.496911 & $\mathbf{- 0 . 7 8 9 1 0 9}$ \\
$\mathrm{P}$ & 0.388903 & $\mathbf{- 0 . 8 4 7 9 3 2}$ \\
$\mathrm{K}^{+}$ & $\mathbf{- 0 . 8 5 3 0 2 0}$ & -0.354186 \\
$\mathrm{Na}^{+}$ & -0.438758 & $\mathbf{- 0 . 8 5 5 8 6 2}$ \\
$\mathrm{Ca}^{2+}$ & $\mathbf{- 0 . 9 6 0 5 2 4}$ & -0.127308 \\
$\mathrm{Mg}^{2+}$ & -0.468431 & $-\mathbf{0 . 7 7 1 4 5 8}$ \\
$\mathrm{H}+\mathrm{Al}$ & $\mathbf{- 0 . 8 1 6 6 6 4}$ & 0.562031 \\
$\mathrm{SB}$ & $\mathbf{- 0 . 9 5 3 5 1 6}$ & -0.267763 \\
$\mathrm{CEC}$ & $\mathbf{- 0 . 9 7 7 7 1 7}$ & 0.176348 \\
$V$ & 0.570922 & $\mathbf{0 . 8 0 5 3 2 9}$ \\
$\mathrm{TOC}$ & $\mathbf{- 0 . 9 6 4 2 0 7}$ & -0.191545 \\
POC & $\mathbf{- 0 . 9 4 7 7 3 3}$ & 0.149509 \\
MOC & $\mathbf{- 0 . 8 2 9 2 0 3}$ & -0.426263 \\
\hline
\end{tabular}

Numbers in boldface represent high correlation (above 0.7) between the factor and the variable.

elevated explanatory capacity. Moreover, the two first factors presented high correlation (above 0.7) with all analyzed variables (Table 5).

The PCA showed a clear separation of at least two groups: to the right, group of samples with FRr; to the left, group of samples with CMd. These, in turn, can be further subdivided into four subgroups, namely, subgroup 1: FRr CON (control); subgroup 2: FRr BPM, FRr BC, and FRr BCM (treatments with EM Bokashi); subgroup 3: CMd CON (control); and subgroup 4: CMd BPM, CMd BC, and CMd BCM (treatments with EM Bokashi). These results clearly show a high potential of PCA for grouping similar samples by means of conjoint analysis of all the studied variables. In comparison to the parametric statistics used in this work, it is possible to suggest even a higher efficiency of this multivariate statistical technique in promoting such grouping. Therefore, it is reasonable to suggest that although little used at present, PCA is a tool that should be better explored for scientific evaluations such as those performed in this work.

The multivariate analysis of fertility and soil organic matter attributes by PCA shows a grouping of different soils treated with EM Bokashi, suggesting their similar efficiency to improve soil fertility potential when compared to the controls. The PCA also suggests that the chemical attributes of CMd were more influenced by the addition of EM Bokashi than FRr. Soils that received BCM present chemical attributes more similar to the controls, while soils fertilized with BPM present more distinguished ones. The $\mathrm{BC}$, in turn, proportioned intermediary changes. Pandolfo et al. [14] that had done a technical analysis of nutrients sources and management systems by models found results that support a better performance of poultry litter to improve a soil chemical index in a Brazilian Rhodic Nitisol when compared with liquid cattle manure. The better performance of poultry litter must be related with its faster decomposition compared to mixed manure (equal proportions of poultry litter and cattle manure), that presents intermediate decomposition rates, and cattle manure [31]. The higher decomposition rates of poultry litter must be associated with its organic matrix that is rich in organic acids with low molecular weight [32].

The Pearson correlations coefficients (Table 6) reinforced some aspects discussed previously with regard to the behavior of fertility attributes, the TOC, and the physical fractions of organic matter. For instance, the high direct correlations existing between $\mathrm{pH}$ and $V$ are very clear. On the other hand, indirect correlations were observed between these variables and the potential acidity $(\mathrm{H}+\mathrm{Al})$. Another direct relationship that stands out is that existing between the organic fractions (POC and MOC) and TOC with CEC, as well as with the contents of exchangeable bases $\mathrm{Ca}^{2+}$ and $\mathrm{K}^{+}$, besides $\mathrm{SB}$, thus suggesting the supply of negative electric charges by the SOM. The strong direct correlation between $\mathrm{H}+\mathrm{Al}$ and $\mathrm{CEC}$ reinforces this suggestion. The fraction POC also strongly and directly correlated with the $\mathrm{Mg}^{2+}$ contents, suggesting relationships such as the nutrient's supply by this fraction. In this work no strong relationships were observed between the contents of $\mathrm{P}$ and those of POC and MOC or TOC fractions. However, it is known that the addition of organic production inputs may reduce the maximum adsorption capacity of $\mathrm{P}$ in Brazilian soils [33]. Furthermore, strong correlations were observed between the contents of this important macronutrient and the values of $\mathrm{pH}$ and $V$. In tropical soils, the high point of zero charge of oxides and oxyhydroxides leads to a higher density of positive charges in the exchange complex under conditions of acid $\mathrm{pH}$, increasing the potential of $\mathrm{P}$ adsorption by the soil. Contrarily, when in basic $\mathrm{pH}$, the generation of negative electric charges occurs in function of deprotonation of clay surface [34], leading to a smaller capacity of $\mathrm{P}$ adsorption.

The results obtained in the present work reinforce the perception that the recommendations for organic fertilization with EM Bokashi must be better developed, considering the characteristics of not only these production inputs, but also soils being fertilized.

\section{Conclusions}

The results found in this paper can support future researches with focus on behavior of organic amendments in different soils types. The interaction between soil organic matter and soil characteristics is well documented in the scientific literature and it is clear that the dynamics of organic matter depends on several factors as soil mineralogy, soil texture, soil microbial community, and relationships between nutrients (e.g., C, N, and P), among others. Thus, it is possible that the same organic amendment presents different nutrient supply in different soils types, as can be noted in the results of this paper. Also, different organic amendments can present different behavior in the same soil. In our opinion, to allow better results in organic agriculture, future researches should be focalized in the relationships of soil organic matter dynamics and nutrients supplies when different organic fertilizers are used in different soils types. 
TABLE 6: Coefficients of correlation of Pearson between the variables evaluated in the present work.

\begin{tabular}{|c|c|c|c|c|c|c|c|c|c|c|c|c|c|}
\hline & $\mathrm{pH}$ & $\mathrm{P}$ & $\mathrm{K}^{+}$ & $\mathrm{Na}^{+}$ & $\mathrm{Ca}^{2+}$ & $\mathrm{Mg}^{2+}$ & $\mathrm{H}+\mathrm{Al}$ & SB & $T$ & $V$ & TOC & POC & MOC \\
\hline $\mathrm{pH}$ & 1.00 & 0.78 & -0.08 & 0.37 & -0.39 & 0.28 & -0.87 & -0.28 & -0.65 & 0.96 & -0.26 & -0.57 & 0.01 \\
\hline $\mathrm{P}$ & & 1.00 & -0.14 & 0.61 & -0.21 & 0.50 & -0.76 & -0.11 & -0.49 & 0.88 & -0.25 & -0.48 & -0.04 \\
\hline $\mathrm{K}^{+}$ & & & 1.00 & 0.64 & 0.80 & 0.62 & 0.46 & 0.87 & 0.73 & -0.19 & 0.93 & 0.74 & 0.93 \\
\hline $\mathrm{Na}^{+}$ & & & & 1.00 & 0.52 & 0.95 & -0.10 & 0.65 & 0.29 & 0.40 & 0.54 & 0.29 & 0.65 \\
\hline $\mathrm{Ca}^{2+}$ & & & & & 1.00 & 0.50 & 0.72 & 0.98 & 0.94 & -0.43 & 0.95 & 0.87 & 0.87 \\
\hline $\mathrm{Mg}^{2+}$ & & & & & & 1.00 & -0.02 & 0.64 & 0.33 & 0.30 & 0.54 & 0.37 & 0.59 \\
\hline $\mathrm{H}+\mathrm{Al}$ & & & & & & & 1.00 & 0.63 & 0.91 & -0.93 & 0.66 & 0.87 & 0.40 \\
\hline SB & & & & & & & & 1.00 & 0.90 & -0.32 & 0.97 & 0.85 & 0.91 \\
\hline CEC & & & & & & & & & 1.00 & -0.71 & 0.90 & 0.95 & 0.72 \\
\hline$V$ & & & & & & & & & & 1.00 & -0.37 & -0.67 & -0.08 \\
\hline TOC & & & & & & & & & & & 1.00 & 0.89 & 0.93 \\
\hline POC & & & & & & & & & & & & 1.00 & 0.66 \\
\hline MOC & & & & & & & & & & & & & 1.00 \\
\hline
\end{tabular}

Numbers in boldface represent high correlation (above 0.7 ) between the factor and the variable.

\section{Conflict of Interests}

The authors declare that there is no conflict of interests regarding the publication of this paper.

\section{Acknowledgment}

This study was funded by Embrapa, Brazilian Agricultural Research Corporation.

\section{References}

[1] P. J. Crutzen, “Geology of mankind," Nature, vol. 415, no. 6867, article 23, 2002.

[2] R. Lal, "Soil carbon sequestration to mitigate climate change," Geoderma, vol. 123, no. 1-2, pp. 1-22, 2004.

[3] J. Rockström, W. Steffen, K. Noone et al., "A safe operating space for humanity," Nature, vol. 461, no. 7263, pp. 472-475, 2009.

[4] D. K. Ray, N. D. Mueller, P. C. West, and J. A. Foley, "Yield trends are insufficient to double global crop production by 2050," PLoS ONE, vol. 8, no. 6, Article ID e66428, 2013.

[5] V. Seufert, N. Ramankutty, and J. A. Foley, "Comparing the yields of organic and conventional agriculture," Nature, vol. 484, no. 7397, pp. 229-232, 2012.

[6] C. L. Boechat, J. A. G. Santos, and A. M. D. A. Accioly, "Net mineralization nitrogen and soil chemical changes with application of organic wastes with 'Fermented Bokashi Compost," Acta Scientiarum. Agronomy, vol. 35, no. 2, pp. 257-264, 2013.

[7] T. H. Seran and N. Suthamathy, "Effect of combined application of cattle manure and EM on the yield and yield components of groundnut (Arachis hypogaea L.)," Bangladesh Journal of Agricultural Research, vol. 38, no. 1, pp. 1-9, 2013.

[8] C. A. Cambardella and E. T. Elliot, "Particulate soil organicmatter changes across a grassland cultivation sequence," Soil Science Society of America Journal, vol. 56, no. 3, pp. 777-783, 1992.

[9] EMBRAPA, Manual de Métodos de Análises de Solos, Embrapa, Rio de Janeiro, Brazil, 1997.

[10] M. M. Ferreira, B. Fernandes, and N. Curi, "Mineralogia da fração argila e estrutura de latossolos da região sudeste do
Brasil," Revista Brasileira de Ciência do Solo, vol. 23, no. 3, pp. 507-514, 1999.

[11] B. van Raij, M. T. D. Sacchetto, and T. Igue, "Correlações entre o pH e o grau de saturação em bases nos solos com horizonte B textural e horizonte B latossólico," Bragantia, vol. 27, no. 1, pp. 193-200, 1968.

[12] Embrapa, Sistema Brasileiro de Classificação de Solos, Embrapa, Rio de Janeiro, Brazil, 2nd edition, 2006.

[13] J. R. Fink, A. V. Inda, J. A. Almeida, C. A. Bissani, E. Giasson, and P. C. Nascimento, "Chemical and mineralogical changes in a Brazilian Rhodic Paleudult under different land use and managements," Revista Brasileira de Ciência do Solo, vol. 38, no. 4, pp. 1304-1314, 2014.

[14] C. M. Pandolfo, C. A. Ceretta, M. Veiga, and A. M. Massignam, "Análise técnica de fontes de nutrientes associadas a sistemas de preparo do solo," Revista Brasileira de Ciência do Solo, vol. 32, no. 2, pp. 759-768, 2008.

[15] N. K. R. Kirithiga, "Effect of formulation of effective microorganism (EM) on post treatment persistence, microbial density and soil macronutrients," Recent Research in Science and Technology, vol. 2, no. 5, pp. 102-106, 2010.

[16] C. H. Abreu Jr., T. Muraoka, and A. F. Lavorante, "Relationship between acidity and chemical properties of Brazilian soils," Scientia Agricola, vol. 60, no. 2, pp. 337-343, 2003.

[17] O. E. A. Ourives, G. M. Souza, C. S. Tiritan, and D. H. Santos, "Fertilizante orgânico como fonte de fósforo no cultivo inicial de Brachiaria brizantha cv. Marandú," Pesquisa Agropecuária Tropical, vol. 40, no. 2, pp. 126-132, 2010.

[18] F. D. O. Gebrim, I. R. da Silva, R. F. Novais et al., "Cation leaching favored by inorganic anions and low molecular mass organic acids in soils fertilized with different poultry litters," Revista Brasileira de Ciência do Solo, vol. 32, no. 6, pp. 2255-2267, 2008.

[19] F. D. O. Gebrim, R. F. Novais, I. R. da Silva et al., "Mobility of inorganic and organic phosphorus forms under different levels of phosphate and poultry litter fertilization in soils," Revista Brasileira de Ciência do Solo, vol. 34, no. 4, pp. 1195-1205, 2010.

[20] P. C. Conceição, J. Dieckow, and C. Bayer, "Combined role of no-tillage and cropping systems in soil carbon stocks and stabilization," Soil and Tillage Research, vol. 129, pp. 40-47, 2013.

[21] A. Loss, M. G. Pereira, N. Schultz, L. H. C. Anjos, and E. M. R. Silva, "Carbono e frações granulométricas da matéria orgânica 
do solo sob sistemas de produção orgânica," Ciência Rural, vol. 39, no. 4, pp. 1077-1082, 2009.

[22] A. Loss, M. G. Pereira, N. Schultz, L. H. Cunha dos Anjos, and E. M. Ribeiro da Silva, "Frações orgânicas e índice de manejo de carbono do solo em diferentes sistemas de produção orgânica," Idesia, vol. 29, no. 2, pp. 11-19, 2011.

[23] J. Six, P. Callewaert, S. Lenders et al., "Measuring and understanding carbon storage in afforested soils by physical fractionation," Soil Science Society of America Journal, vol. 66, no. 6, pp. 1981-1987, 2002.

[24] C. P. Giardina and M. G. Ryan, "Evidence that decomposition rates of organic carbon in mineral soil do not vary with temperature," Nature, vol. 404, no. 6780, pp. 858-861, 2000.

[25] E. A. Davidson and I. A. Janssens, "Temperature sensitivity of soil carbon decomposition and feedbacks to climate change," Nature, vol. 440, no. 7081, pp. 165-173, 2006.

[26] C. E. G. R. Schaefer, J. D. Fabris, and J. C. Ker, "Minerals in the clay fraction of Brazilian latosols (Oxisols): a review," Clay Minerals, vol. 43, no. 1, pp. 137-154, 2008.

[27] A. Piccolo and J. S. C. Mbagwu, "Role of hydrophobic components of soil organic matter in soil aggregate stability," Soil Science Society of America Journal, vol. 63, no. 6, pp. 1801-1810, 1999.

[28] W. Zech, N. Senesi, G. Guggenberger et al., "Factors controlling humification and mineralization of soil organic matter in the tropics," Geoderma, vol. 79, no. 1-4, pp. 117-161, 1997.

[29] K. Lorenz, R. Lal, C. M. Preston, and K. G. J. Nierop, "Strengthening the soil organic carbon pool by increasing contributions from recalcitrant aliphatic bio(macro)molecules," Geoderma, vol. 142, no. 1-2, pp. 1-10, 2007.

[30] W. S. Lyra, E. C. Silva, M. C. Araújo, and W. D. Fragoso, "Classificação periódica: um exemplo didático para ensinar análise de componentes principais," Química Nova, vol. 33, no. 7, pp. 1594-1597, 2010.

[31] V. B. da Silva, A. P. da Silva, B. D. O. Dias, J. L. Araujo, D. Santos, and R. P. Franco, "Decomposition and mineralization of N, P and $\mathrm{K}$ of cattle manure and poultry litter isolated or mixed," Revista Brasileira de Ciencia do Solo, vol.38, no. 5, pp. 1537-1546, 2014.

[32] L. C. A. Melo, C. A. Silva, and B. D. O. Dias, "Characterization of the organic matrix of residues from different origins," Revista Brasileira de Ciência do Solo, vol. 32, no. 1, pp. 101-110, 2008.

[33] R. F. Souza, V. Faquin, P. R. F. Torres, and D. P. Baliza, "Calagem e adubação orgânica: influência na adsorção de fósforo em solos," Revista Brasileira de Ciência do Solo, vol. 30, no. 6, pp. 975-983, 2006.

[34] M. P. Fontes, O. A. Camargo, and G. Sposito, "Eletroquímica das partículas coloidais e sua relação com a mineralogia de solos altamente intemperizados," Scientia Agricola, vol. 58, no. 3, pp. 627-646, 2001. 


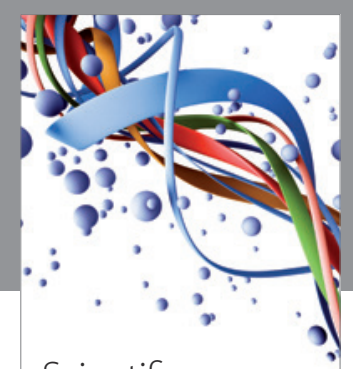

Scientifica
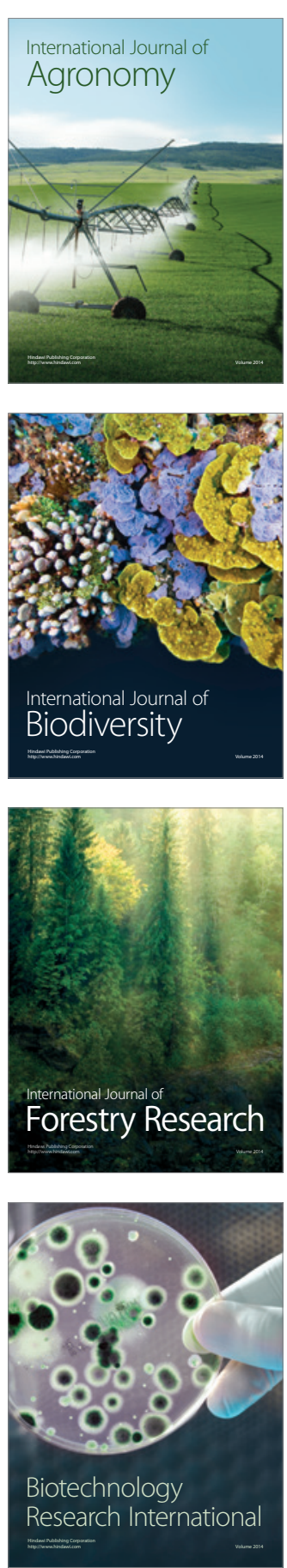
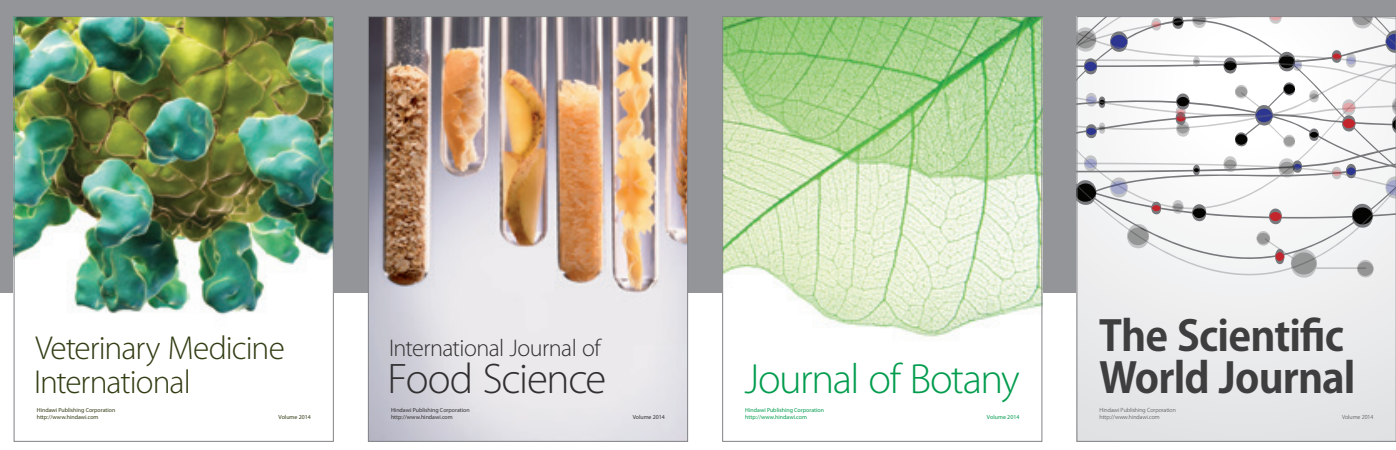

The Scientific World Journal
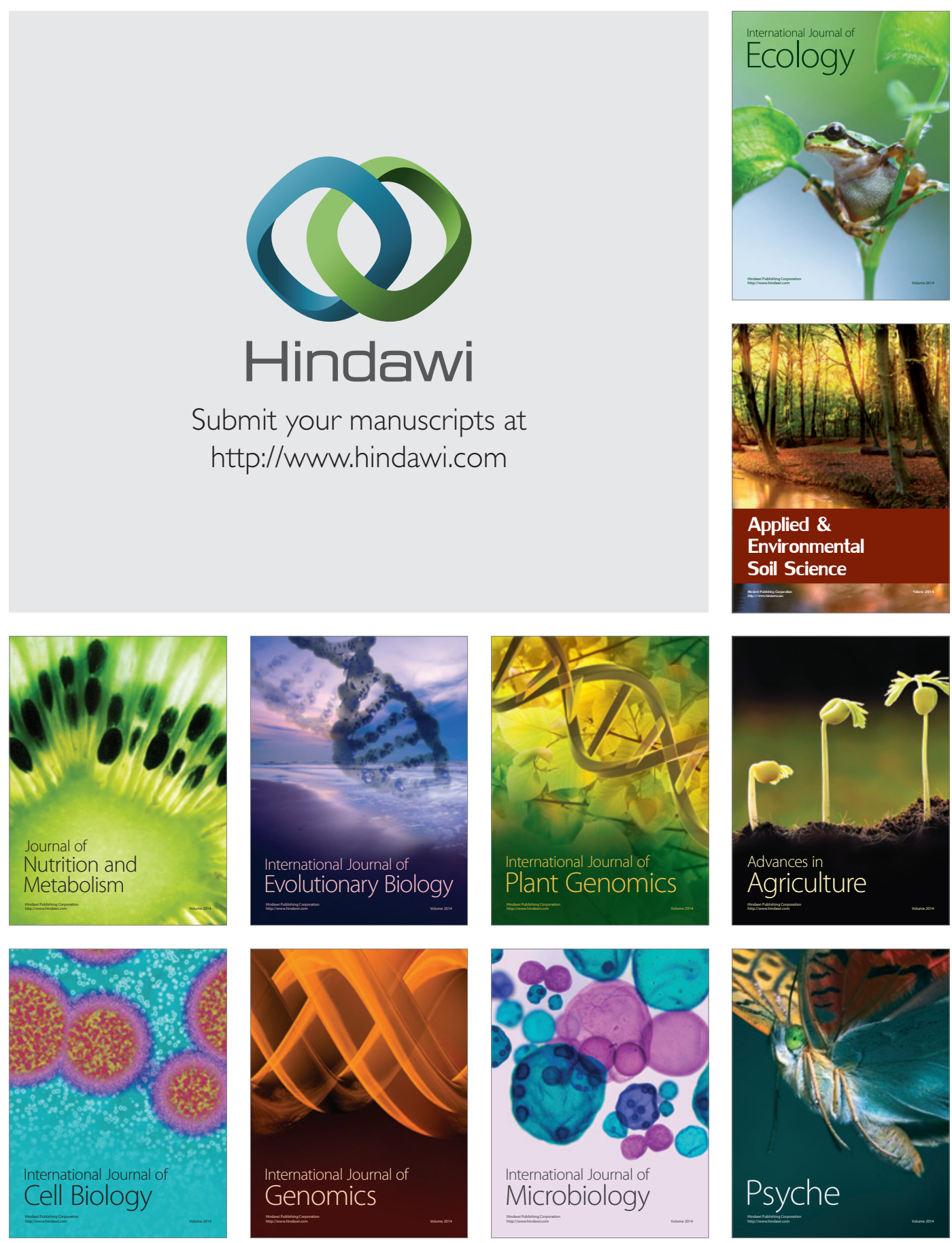